\title{
Does Globalization Improve Women's Educational Status?
}

\author{
Sirous Tabrizi \\ University of Windsor \\ Canada
}

\begin{abstract}
Globalization has many positive and negative effects on national economics worldwide such as poverty eradication, availability, technology, foreign investment, terrorism, job and price instability, and currency fluctuation. As well one fundamental effect of globalization is enhanced demand for education. Some people who research globalization believe realizing such as a demand will ameliorate the wellbeing and life of and provide more job opportunities to citizens especially women. This paper will critically investigate the effects of globalization, either positive or negative, on women's education.

However, in particular, this article will examine hidden and unhidden issues: 1) globalization raising the rate of return to women's education, 2) a worldwide movement for women's rights, 3) increasing demand by women for higher education levels, and 4) women still being discriminated against in labour markets. Eventfully, the results are mixed and the situation is complex. Payoff for women's education has been resulted by trade liberalization and economic globalization (e.g., women taking advantage of increasing demand for educated workers).

Even though after the emergence of globalization women have been able to find more job positions, their work type and career prospects are often worse than those of men. Moreover, the connection between women's education, well-being, and economic position is still unclear.
\end{abstract}

\section{Introduction}

This article attempts to examine five main globalization-related subjects and its effects on women's education such as 1) some positive and negative impacts of globalization on women's education, 2) globalization raising the rate of return to women's education, 3) a worldwide movement for women's rights, 4) increasing demand of women for higher education levels, and 5) women still being discriminated against in labour markets.

\section{Discussion}

Does globalization improve the women's educational status? According to Carnoy [6]:
"The answer lies in two parts. The first is economic: rising payoffs to higher education in a global, science based, knowledge intensive economy makes university training more of a "necessity" to get "good" jobs. This, in turn, changes the stakes at lower levels of schooling, and drastically changes the function of secondary school. The second part is socio-political: demographics (the changing family) and democratic ideals increase pressure on universities to provide access to groups that traditionally have not attended university." (p. 4).

Stromquist and Monkman [17] note that globalization has fundamental effects on market labour; in particular, globalization increases demand for education. This growth puts pressure on the system for higher quality schooling, often producing perverse consequences, mainly with respect to educational equality. In addition, globalization also has an effect on racial equality: increased global economic competition and the new organizations and technology that emerged have hindered black job mobility and were more favourable to white skills and work styles [5]. Because of this, equalization would be more difficult to achieve even if government were willing to make the effort. Although this is the case, race cannot be ignored. Carnoy [5] concludes that inequality of wage distribution, based on race, is a result of increased global competition.

Additionally, challenges of globalization have introduced two opposite trends in education: 1) higher decentralization, with all community groups (ethnicity-based organizations, gender-based social movement, religious organizations) developing their own education, and 2) a centralized, multi-cultural self-knowledge approach to socialize all young people in the public system. The state continues to impose its ideological perspective on education, but one reflecting the diversity of today's post-industrial societies. Although the decentralized approach assumes that market relations are enough to keep diverse societies working together, a push for decentralization of education delivers increased inequality of educational services, because the capacity to deliver educational services varies among communities [11]. These trends will be addressed later in this paper, while the rest of the discussion sequentially examines the four issues mentioned in the introduction. 


\subsection{Some positive and negative impacts of globalization on women's education}

Globalization demonstrates how diverse cultures, economies, and populations are interdependent on each other, meaning that it is a consequence of transboundary. Its most common components are technology, investment, goods, information, services, and labour markets. Globalization has been established with a worldwide integration over many centuries by nations' political, economic, and social challenges. However, globalization has some positive and negative effects on women's life. In this section, these effects will be reviewed.

Positive effects. In developed and developing countries many researchers have identified several positive effects of globalization such as global market, cross-cultural management, reducing the gap between the rich and the poor, investment, advanced technology, positive effects on developing countries, poverty eradication, availability of employment, education, technology, and foreign investment.

In this section, some of these positive effects will be discussed [8].

"Both neo-liberalization and neo-conservatism seek to create opportunities for citizens, they use slightly different means and their impact on education may hamper creating positive outcomes for citizens" [19]. Furthermore, these schools prefer to develop the global market, i.e. they encourage nations to produce a multitude of commodities that are available in their local markets. In other words, different countries will produce diverse goods where there is no selfsufficient country. Therefore, the larger market will be able to return more income and job opportunities to developed and developing countries, and also the cross-border market encourages companies to invest in diverse markets to produce more economic goods.

One of the effects of global market pertains to incorporation of all cultures to form a global one, consequently, we witness that in many developing countries, females are allowed to acquire higher education and do jobs in their specialized fields.

One of the main effects of globalization is helping developing countries to recognize and utilize their resources efficiently. Majority of their populations used to be uneducated or low-educated with no access to standard transport infrastructure. Nowadays not only did many of these countries succeed to establish and develop higher education but also, a high percentage of the young population continue their education in developed countries that it has become advantageous to achieve a certificate to advance their careers. Brain circulation between developing and developed countries is a fundamental reason to establish globalization. Consequently, due to globalization, many companies capable of competing with rivals from developed countries were established and managed by themselves [8].

The transfer of technology to developing countries has increased with expansion of globalization as well as technology-enhanced globalization. Modern technology has helped investors and foreigners to be more successful in the technology transfer process which has greatly changed people's lives in developing countries. Therefore, factories easily get the raw material and manpower needed to produce goods and the citizens in developing countries have many new jobs.

Negative effects. Globalization increased the number of people who are seeking different jobs with diverse level of skills all over the world, hence, employers can exploit cheap labour. Therefore, employers are able to fire employees even at a slight mistake, with employees preferring to decrease their creativity and risk-taking. However, in these organizations effectiveness suffers and employees' will just improve their efficiency. As well the hidden side of globalization is also significant. After transferring industrial factories to developing countries, many poor families have to send their girls and wives to work as simple workers. They all have to work almost 20 hours per day and seven days a week during the month, supervised by men in masculine environments. Industrial owners who established their business overseas insisted on hiring the cheapest material and manpower and selling their goods at a reduced price. Some other negative effects of globalization such as terrorism, price instability, and currency fluctuation were discussed but are not related to the subject of this article [8].

\subsection{Globalization raising the rate of return to women's education}

In many countries, rates of return for education for women are higher than men. There are two main factors for the increased participation of women in labour markets: the spread of feminist ideas and values, and the increased demand for low-cost, semiskilled labour in developing countries' electronics manufacturing and other assembly industries [13]. Due to trade liberalization, there is an increasing demand for labour-intensive manufactured goods, such as textiles, apparel, electronics, and food processing. Because of their low wages relative to men, women are an attractive source of labour for firms [7]. Fontana and colleagues state [9]:

"Women's universally disadvantaged position in labour markets in developing countries - the wage and job discrimination they face - paradoxically redounds to their advantages under the competitive, at least in those countries which have a comparative advantage in labour-intensively produced goods.” (p.49).

Kawach and Wamala [12] suggest that trade liberalization should therefore lead to increased 
female employment. Increased export volume due to liberalization should result in the following [12]:

1) Increased participation of women in paid employment, and therefore decreased gender gaps in labour force participation, as well as improved opportunities for women's economic, social and political participation.

2) Decreased unemployment rates for women and therefore a reduced gender gap in unemployment.

3 ) Higher wages for female workers and therefore a decreased gender gap in earned income.

According to the United National Research Institute for Social Development (UNRISD), some empirical evidence suggests that women's labour market participation and share of employment have risen over the last two decades in developing countries as a result of liberalized trade and foreign direct investment [22]. The increased trade (export expansion) in some regions, such as Southeast Asia and Latin America, has resulted in an increase in female employment. Although there are benefits for women from trade liberalization, the gains in employment are also often precarious. For example, trade increases women's access to labour markets, but they may find themselves locked in "dead-end" jobs with low pay, poor working conditions, and little opportunity for skill acquisition or advancement. In addition, some women's jobs have been phased out due to gender discrimination, as export production is diversified and manufacturing becomes more capital intensive [10]. The maturation of developing countries leads to loss of labour-intensive manufacturing jobs to even lower wage countries, and, as a result, women are usually the first to be laid off [3]. In rapidly industrializing economies, such as Taiwan, Korea, and Thailand, data suggest that there has been a net decline in women's share of employment in the manufacturing sector during 19912000 [3]. Likewise, Fontana and colleagues [9] explain that:

"the share of women has fallen markedly in exportprocessing zones in Singapore and Mexico, prompting one interpretation of trade expansion as offer[ing] women a once-off benefit in terms of improved access to labour market, but with no sustained improvements in labour market status thereafter" (p. 49).

Although there are benefits and drawbacks for women with respect to trade liberalization, there is some disagreement as to its application to the United States. For example, some economists [4] found that, after controlling for gender difference in educational attainment and labour market experience in the US, increased competition through trade did appear to contribute to an improvement in female wage in concentrated disciplines relative to already competitive industries. In other words, although trade may raise wage inequality, at the same time it appeared to benefit women by reducing the ability of firms to discriminate.

The UNRISD, however, has found that not all empirical studies agree with the findings for the United States just described. Although there may be some positive data, there are counteracting forces to the benefits to women. One of these counteracting forces is the tendency to "crowd" women in labourintensive sectors of the market, leading to an artificial oversupply of female labour [22]. Due to the constant pressure to keep costs low, women's employment conditions make it structurally difficult for firms to raise their wages and to close the gender wage gaps. Although the data may seem inconsistent, it seems trade liberalization has resulted in downward pressure on women's wages in countries such as China, Hong Kong, and Taiwan [22].

\subsection{Worldwide movement for women's rights}

The worldwide movement for women's rights has had the effect of legitimizing equal education for women, women's control over their fertility rates, women's increased participation in wage labour markets, and women's right to vote [13]. The strength of the 19th and early 20th century struggle for women's suffrage was its transnational nature, and the following six international movements bolstered its momentum:

1) The International Women's Suffrage Association, established between 1899 and 1902 . After gaining the right to vote in 1920, women engaged in little independent political movement of the decade resulted in a growing awareness of rights for rights for all groups, including women. In 1966 the National Organization for Women (NOW) was formed to address discrimination against women. Many observers consider the founding of NOW to be the beginning of the modern women's movement-the feminist movement. NOW immediately adopted a blanket resolution designed "to bring women into full participation in the main stream of American society now, exercising all the privileges and responsibilities thereof in truly equal partnership with men." [2].

2) Worldwide Temperance Movement. Perhaps no other cause helped the women's suffrage movement as much as the temperance movement. In 1884 Frances Willard formed the World's Women's Christian Temperance Union (WCTU), which was spearheaded mostly by missionaries working in nonwestern and southern countries. When Willard saw the link between women voting and temperance, and encouraged her membership to work for the vote, the WCTU leadership skills and organizational resources everywhere provided an enormous boost to sometimes flagging suffrage causes [21].

3) International Socialism: In 1907 international socialism decided to support women's suffrage. As women were banned from party membership, 
Socialists had to organize women separately from men in order to create successful female-oriented movements in some countries. This often led to a fundamental challenge to gender relations. German Socialists, for example, demanded sexual emancipation and more control for women within their families as well as the vote [21].

4) The League of Nations and United Nations: These international organizations were a significant help toward the goal of universal female suffrage. In 1946 a Commission on Women was established, and the Convention of the Political Rights for Women was adopted in 1952 [21].

5) Various coalitions within regions and pannational groups also strengthened individual movements. For instance, although Latin American women participated in several inter-American and European conferences, they had more success when they formed supportive alliances within the South American continent. The first South American International Feminine Congress took place in Buenos Aires in 1910 [21].

6) Pan-Pacific Women's Networks: These networks became effective advocates of women's political equality, as did networks within countries with many regions. As an example, by the end of the nineteenth century, women in India were forming their own organizations. The first all-India organization, the Women's Indian Association, was established in 1917, and by 1918 was holding gatherings all over India in support of women's franchise [21].

\subsection{Increasing demand of women for higher education levels}

In the current globalized economy, more students want to attend universities. Even in underdeveloped countries a large group of students, especially females, believe that a high degree of education can provide a better life situation. For example, Rezai Rashti [14] states "it is clear that women's access to higher education has improved significantly in recent years" (p. 93). Evidence for this statement is that women in Iran gained incredible access to higher education and that their participation in the labour market increased, especially in the late 1990s [14]. However, the increase in education was much lower than the increase in women's participation in the labour market.

Bloom's taxonomy in his model refers to the six major levels for the knowledge-based domain: remembering, understanding, applying, analyzing, evaluating, and creating (see Figure 1). These six levels cover a continuum from simple (remember) to complex (create), and concrete to abstract. Bloom's taxonomy levels are organized by increasing complexity, meaning that, lower levels of model involve less sophisticated measurement of students' learning outcome [20]. For example, even if low levels such as 'remembering' or 'understanding' can be measured through a simple multiple-choice exam, higher levels like 'evaluating' or 'creating' would require longer written responses, oral discussion, or presentations in order to measure the outcomes [20].

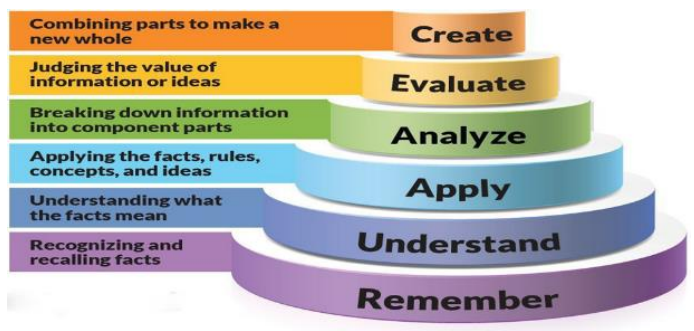

Figure 1. Diagram showing the knowledge-based categories of Bloom's taxonomy (from [1])

Furthermore, this trend of increased desire for education imposes more pressure on universities to accept more students. University education has also expanded, but, given the bias of global demand for higher education, the tendency is to push up rates of return to investment in higher education relative to payoffs in investing in primary and secondary school [17]. In countries such as Singapore, Malaysia, Hong Kong, the Republic of Korea, Argentina, and others in the Organization for Economic Cooperation and Development (OECD), the rates of return for university education is higher than the rates for either secondary or primary education. Additionally, higher rates of return for higher education mean that those who get such an education are benefited relatively more for their investment than those who stop at lower levels of schooling. This higher rate of return has a relationship to socioeconomic status. For example, in most countries, those who get to higher levels of schooling are also those from a higher social class background [17]. As a result, students from a higher socioeconomic state (SES) get access to "better" schools. Competition for such higher-pay-off education also increases as the payoff to higher education increases, because the stakes get higher. The result is that national economic competition on a global scale gets translated into sub-national competition in class access to educational resources [17]. Although this is general trend affects both males and females, existing discrimination towards women compounds the effect on their educational status.

\subsection{Women still being discriminated against in labour markets}

According to Rizvi and Lingard [15]:

"Gender equality in education is an important policy priority in both Education For All (FEA) and Millennium Development Goal (MDG) declarations. It is now widely agreed that without gender equality 
no society can claim to be socially just. It should be achieved complete gender equity; and that, as a concept, it is interpreted differently across religious, political and cultural traditions" (p. 150).

Not surprisingly therefore, policy requirements and outcomes around issues of gender equity work differently across the developed and developing nations. Boys become the focus of much gender policy in the developed nations while girls' access to schooling remaining the dominant gender issue in education policy in developing nations. As these two situations are different, the approaches to educational policies designed to promote gender equity are at variance with each other [15].

In recent years, organizations such as the OECD, the World Bank, and UNESCO have repeatedly emphasized the importance of gender equity for all levels of education. Though the ideological stances of these three organizations are different, they all seem to use similar arguments in support of gender equity in education [15]. For instance, the World Bank cites research that women and girls that work harder than men are more likely to invest their earning in their children, and are major producers as well as consumers. UNESCO argues that educating girls yields the highest return in economic terms. Finally, the OECD urges that investing in women (with respect to education, health, family planning, access to land, etc.) directly reduces poverty and leads to higher productivity and a more efficient use of resources. Note that all three of these organizations view the significance of equity largely in terms of market efficiency. Rizvi and Lingard argue that this is because policies relating to gender equality in education remain tied to the neo-liberal imaginary view of equity largely in instrumental economic terms [15].

In any case, gender equity requires both an investigation of the social processes that perpetuate gender inequalities, as well as a reexamination of the purpose of education. Viewing education and equality strictly in economic terms is not sufficient to bring about equality of men and women. The ways in which education is administered, and the curriculum and pedagogy, need to be reexamined and have potential to reshape patterns of both economic and social relation [15].

The increased demand for low-cost labour, and the greater sense by women that they have the same rights as men, has brought an enormous number of married women into the labour market worldwide. This, in turn, has created increased demand for education levels. So, globalization is accentuating an already growing trend by women to obtain at least as much education as men [17]. Although this is the case, it does not mean that women receive wages equal to men's. Nor does it mean that women are obtaining higher education in fields that are most lucrative, such as engineering, business, or computer science [17].
Women are still vastly underrepresented in these professions, even in the most "feminized" countries such as Sweden and the United States [5]. However, the effect of globalization seems to be gradually changing that, with both positive and negative results. The positive results are that women are generally at least as flexible as men, an increasingly desirable trait, and that information technology and telecommunications are spreading democratic ideas worldwide. The negative results are that, globally, women are paid much less than men and firms profit by hiring women and paying them lower wages. Both the positive and negative aspects seem to be increasing both the education and the price of women's labour relative to men's. For example, the percentage of women in science and engineering university programs is increasing worldwide [5]. Although such increased "professionalization" of women may have costly effects on family life, it does serve to democratize societies and greatly raise the average level of schooling [5].

\section{Conclusion}

Globalized demand for certain types of higherlevel skill puts upward pressure on the pay offs to the higher educated around the world, particularly in those economies more closely tied into the globalization process. According to Stromquist and Mankman [17]:

"In the past generation, most countries have undergone rapid expansion of their primary and secondary education systems. This is not universally true, but thanks to a generalized ideology that basic education should be available to children as a right, even financial constraints in many debt-ridden countries, such as those in Latin America, did not prevent them from increasing access to basic and even secondary education" (p. 53).

This can be expanded upon by mentioning two different perspectives on globalization and education. From a financial perspective, most governments are under pressure to reduce public spending on education and to find new sources of funding. From an educational perspective, national educational systems are increasingly being compared to other nations, placing increased emphasis on curriculum, standards, and testing. As a result, there is an increased focus on accountability. To this end, testing and standards can measure knowledge production and can therefore be used to assess education workers (teachers) and managers.

This paper discussed economic globalization and, in particular, trade liberalization and its relationship to increased payoff for women's education. As such, one can ask whether these issues promote women's autonomy or not. In fact, they have both positive and negative effects. 
The effect of globalization on the status of women is a central theme in the study of contemporary women worldwide. Globalization can be defined as the movement toward global capitalism and culture. Critics of globalization point to policies that favour work performed by men at the expense of informal modes of work performed by women, particularly in the developing countries [23]. In these developing countries, there is a struggle to pay off high-interest loans to developed countries. As a result, public subsidies that support social programs for women and children are diminished. Another general effect of globalization is the well-being of women. Today, there is a global and quickly growing trade in women's bodies that is grossing over six billion dollars annually for the traffickers [23]. The UN estimates that about four million women are being trafficked as sex slaves, and 50,000 are brought into the US every year, predominantly from the Ukraine, Albania, the Philippines, Thailand, Mexico and Nigeria. Women from China, Malaysia, Indonesia, South Korea, Colombia and Vietnam are used in both legal and illegal Australian brothels. Women are sold for $\$ 4000$ - $\$ 5000$ for short-term contracted work and are then forced to pay off the fee for their "owners" by free "servicing" of up to 500 men, in 12-plus hour shifts, seven days a week, before earning a low fee for sexual services [23]. Another effect of globalization on the status of women in developing countries is their job conditions. The owners of industrial companies in developing countries hire many women earning low incomes without any perks, pay raise, or prospects. Meaning that, in many low-income countries such as China, South Africa, Thailand, Poland, Bangladesh, and Brazil women are paid less than in developed countries like the United States.

Other scholars believe there are positive effects to globalization such as women's political representation (in formal governmental institutions), the liberalization of traditional gender roles, and increased education [21]. They argue that the increased political presence of women is a result of the positive effects of globalizations. One example is Chile electing their first female president in 2007. Another example is the Brazilian constitution of 1988 , which formed the Council on the Condition of Women (subsequently named The National Council on Women's Rights). This council implemented a family planning program, extended maternity leave, facilitated the establishment of a special police force to end sexual abuse and domestic violence, ended the prohibition of abortion, and successfully promoted a women's agenda. Other women have also made inroads into state power in Latin America, such as increased Latin American opposition groups. In 1988, Chilean women fought against President Pinochet's military authoritarian rule and demanded the recognition of human rights. The Mothers of the Plaza del Mayo in Argentina played a decisive role in the defeat of the dictatorship there [21]. Some scholars also argue that the economic growth from trade liberalization results in an improvement to women's well-being, though others have suggested that economic growth does not automatically lead to increased well-being [16].

Education system in many countries only support the lower levels of Bloom's taxonomy in both secondary and higher education such that teachers prefer to evaluate students' learning outcomes through simple multiple-choice exams [18]. Thereupon, graduates in different disciplines do not have the required skills to perform their responsibilities satisfactorily or accept multiple responsibilities, hence, many of the company owners utilize their skill as a simple worker. In other words, many graduates only start to learn in their work organizations.

This paper examined five issues in relation to globalization and increased payoff to women's education. Although payoffs seem to be increasing, and trends show the situation is getting better, there are clearly both positive and negative effects of globalization for women. The intention of this paper was to demonstrate that it is a complex issue and is not wholly good or bad, and that it requires deep examination of all of the factors affecting each other.

\section{References}

[1] Anderson, L.W., D.R. Krathwohl, P. Airasian, K. Cruikshank, R. Mayer, P. Pintrich, ... \& M. Wittrock, $A$ taxonomy for learning, teaching and assessing: A revision of Bloom's taxonomy, New York, Longman Publishing, 1992.

[2] Bardes, B.A., Shelley, M.C., \& Schmidt, S.W, American Government and Political Today: The Essential 2008 Edition, Cengage Learning Inc., 2009.

[3] Berik, G., "Mature export-led growth and gender wage inequality in Taiwan," Feminist Economics, vol. 6, no. 3, pp. 1-26, 2000.

[4] Black, S.E., \& Brainerd, E., Importing equality? The impact of globalization on gender discrimination, the National Bureau of Economic Research, Working Paper no 9110, Cambridge, MA, 2002.

[5] Carnoy, M., International encyclopedia of economics of education, Elsevier Science Ltd., 1995.

[6] Carnoy, M., Globalization, educational trends and the open society, Stanford University, School of Education, 2005.

[7] Elson, D., \& Pearson, R., "The subordination of women and the institutionalization of factory production," in Young, C., \& McCullagh, C. (Eds.), Marriage and the Market: Women's Subordination in International Perspective, pp. 59-80, Routledge, London, 1981. 
[8] Essays, UK. "Positive and negative effects of Globalization", UK Essays Providers of Free Study Resources, 2018, retrieved from https://www.ukessays.com/essays/economics/positive-andnegative-effects-of-globalisation-for-business-economicsessay.php?vref $=1$

[9] Fontana, M., Joekes, S., \& Masika, R., Global trade expansion and liberalization: gender issues and impacts, Report No. 42, the Department for International Development, Brighton, UK, Institute of Development Studies, 1998.

[10] Joekes, S., Trade-related employment for women in industry and service in developing countries, UNRISD Occasional Paper No. 5, United Nations Research Institute for Social Development, Geneva, 1995.

[11] Jun, J.S., \& Wright, D.S., "Globalization and Decentralization: An Overview," Globalization and decentralization: Institutional contexts, policy issues, and intergovernmental relations in Japan and the United States, vol. $1,1996$.

[12] Kawachi, I., \& Wamala, S., Globalization and Health, Oxford University Press Inc., 2007.

[13] Ramirez, F., Saysal, Y., \& Shanahan, S., "The Changing Iogic of Political Citizenship: Cross National Acquisition of Women's Suffrage Rights 1890 to 1990," American Sociological Review, vol. 62, pp. 735-745, 1997.

[14] Rezai Rashti, G.M., “Iranian women's increasing access to higher education but limited participation in the job market," Middle East Critique, 2011.

[15] Rizvi, F., \& Lingard, B., Globalizing Education Policy, Routledge, 2010.

[16] Seguino, S., "Gender inequality and economic growth: a cross-country analysis," World Development, vol. 28, no. 7, pp. 1211-1230, 2000.

[17] Stromquist, N.P., \& Mankman, K., Globalization and Education, Rowman and Little Field Publishers Inc., 2000.

[18] Tabrizi, S. Global Model of Educational Leadership: Islamic and Western Approaches. Lambert Academic Publishing: Saarbrücken, Germany. 2018.

[19] Tabrizi, S. Connections between Neo-Liberalism, NeoConservatism, and Critical Democracy in Education. International Journal for Cross-Disciplinary Subjects in Education (IJCDSE), Special Issue, 4 (1). 1922-1929. 2014.

[20] Tabrizi, S. \& G. Rideout, Active Learning: Using Bloom's taxonomy to support critical pedagogy. International Journal for Cross-Disciplinary Subjects in Education (IJCDSE), 8(3). 3202-3209. 2017.

[21] The-Crankshaft Publishing, "Women and politics," 2011, retrieved from http://what-when-how.com/socialsciences/women-and-politics-social-science/.

[22] United Nations Research Institute for Social Development (UNRISD), "Gender Equality: Striving for
Justice in an Unequal World", Policy Report on Gender and Development: 10 Years after Beijing, UNRISD, Geneva, 2005.

[23] Wilson, O., "Globalized Female Slavery," Prostitution Research and Education, 2000, retrieved from http://prostitutionresearch.com/pub_author/onnie-wilson/. 